\title{
In vitro hydrolysis by pancreatic elastases I and II reduces $\beta$-lactoglobulin antigenicity
}

\author{
M Gestin ${ }^{1}$, C Desbois ${ }^{1}$, I Le Huërou-Luron ${ }^{1 *}$, V Romé ${ }^{1}$, \\ G Le Dréan ${ }^{1}$, T Lengagne ${ }^{2}$, L Roger ${ }^{2}$, F Mendy ${ }^{3}$, P Guilloteau ${ }^{1}$ \\ 'Laboratoire du Jeune Ruminant, INRA, 65, rue de Saint-Brieuc, 35042 Rennes Cedex; \\ ${ }^{2}$ Nutrinov, 85, rue de Saint-Brieuc, 35042 Rennes Cedex; \\ ${ }^{3}$ 1, Place de Béarn, Saint-Cloud, France
}

(Received 15 November 1996; accepted 19 December 1996)

\begin{abstract}
Summary - Bovine whey proteins such as $\alpha$-lactalbumin and $\beta$-lactoglobulin are with bovine caseins the most commonly used proteins in infant formulas owing to their high nutritional value. However, these cow milk components are not always well tolerated and can induce allergies in infants. The purpose of this study was therefore to investigate the gastric (pepsin) and pancreatic (trypsin, chymotrypsin and elastases I and II) enzymatic hydrolysis of $\beta$-lactoglobulin with the aim of finding a means to reduce its antigenicity. Elastases I and II were first purified from porcine pancreatic acetone powder. After differential precipitation steps, elastases I and II were separated by cation-exchange chromatography. The conditions regarding $\beta$-lactoglobulin hydrolysis by gastric and/or pancreatic enzymes were similar to those used for hypoallergenic milk preparations. Elastase II and to a lesser extent elastase I, were effective in enhancing $\beta$-lactoglobulin hydrolysis via a mix of pepsin, trypsin and chymotrypsin and in reducing the residual antigenicity of hydrolytic products. The same hydrolytic percentage was observed when elastase I or II were added, while the residual antigenicity was lower in the presence of elastase II than in the presence of elastase I. The introduction of elastases in the pancreatic mix can therefore be proposed to enhance the hydrolysis of cow milk components in hypoallergenic milk preparations.
\end{abstract}

ß-lactoglobulin hydrolysis / pancreatic elastases I and II / residual antigenicity / hypoallergenic milk

Résumé - L'hydrolyse in vitro de la $\beta$-lactoglobuline par les élastases I et II pancréatiques réduit son antigénicité. Les protéines sériques du lait de vache telles que l' $\alpha$-lactalbumine et la $\beta$-lactoglobuline, de haute qualité nutritionnelle, sont avec les caséines bovines les plus couramment utilisées dans les laits de remplacement. Toutefois, ces protéines laitières ne sont pas toujours tolérées et peuvent induire des réactions de nature allergique chez les nourrissons. Afin de réduire l'antigénicité

* Correspondence and reprints 
de la $\beta$-lactoglobuline, des hydrolyses par des enzymes gastrique (pepsine) et pancréatiques (trypsine, chymotrypsine et élastases I et II) sont réalisées. Une purification des élastases est effectuée à partir de poudre acétonique de pancréas de porc. Après les étapes de précipitation fractionnée, les élastases I et II sont séparées par chromatographie échangeuse de cations. Les conditions d'hydrolyse de la $\beta$ lactoglobuline par les enzymes gastrique et/ou pancréatiques sont celles utilisées dans l'industrie pour la fabrication des laits hypoallergéniques. L'élastase II et dans une moindre mesure, l'élastase I augmentent l'efficacité de l'hydrolyse de la $\beta$-lactoglobuline par le mélange pepsine, trypsine et chymotrypsine et réduisent l'antigénicité résiduelle de ses produits d'hydrolyse. Le même pourcentage d'hydrolyse est obtenu en additionnant l'élastase I ou l'élastase II. Cependant, l'antigénicité résiduelle est plus faible en présence d'élastase II. Ainsi, l'adjonction d'élastases dans un mélange pancréatique pourrait améliorer l'hydrolyse des protéines dans la fabrication des laits hypoallergéniques.

hydrolyse de la $\beta$-lactoglobuline / élastases I and II pancréatiques / antigénicité résiduelle / lait hypoallergénique

\section{INTRODUCTION}

Bovine whey proteins such as $\alpha$-lactalbumin and $\beta$-lactoglobulin are with bovine caseins the most commonly used proteins in infant formulas owing to their high nutritional value. They differ qualitatively and/or quantitatively from human milk proteins. In addition to a high casein level ( 80 vs $35 \%$ of total protein in human milk), cow milk contains $50 \% \beta$-lactoglobulin in whey proteins. This globular protein is lacking in human milk. These cow milk components are not always well tolerated, since about $3 \%$ of children under 2 years of age present allergic reactions. The allergic reactions are promoted by rapid absorption of incompletely digested milk products. This partial digestion may be explained by a low gastric acidity during infancy along with the high buffering capacity of milk (Mason, 1962) and possibly a deficient proteolytic response, particularly as regards elastase II, in the digestive tract of infants suffering from cow milk allergy (Jakobsson et al, 1983).

In order to prevent atopic disease, protein hydrolysates are now given as of birth for several months to an increasing number of infants (Rigo et al, 1994). Pepsin associated with trypsin or chymotrypsin hydrolysis constitutes an efficient combination of enzymes to reduce in vitro allergenicity of $\alpha$-lactalbumin and $\beta$-lactoglobulin (Pahud et al, 1985; Asselin et al, 1988, 1989). Heat treatment of whey proteins has been shown to reduce antigenicity, but has been associated with a loss of available lysine (Heppell et al, 1984; Jost et al, 1987). According to Jost et al (1987), combining selective hydrolysis by specific proteases with processing or subsequent heat treatments appeared to be a promising approach in developing a hypoallergenic infant formula. However, very few studies have investigated the action of pancreatic proteases other than trypsin and chymotrypsin on milk protein. Elastase II, which specifically cleaves globular protein, could improve milk protein hydrolysis. The hydrolysis rate of bovine casein, $\alpha$-lactalbumin and $\beta$-lactoglobulin by human cationic elastase (elastase II-like) exceeds the hydrolysis rate by human anionic and cationic trypsins or anionic elastase (elastase I-like) (Jakobsson et al, 1983). Elastase I hydrolyses both $\alpha$-lactalbumin and $\beta$-lactoglobulin at a moderate hydrolytic rate, producing large and very small peptides, respectively (Schmidt and Poll, 1991).

The purpose of this study was therefore to investigate gastric (pepsin) and pancreatic (trypsin, chymotrypsin and elastases I and II) enzymatic hydrolysis of $\beta$-lactoglobulin as 
a means of reducing $\beta$-lactoglobulin antigenicity. The purified elastase II is not available commercially; we therefore had to purify pancreatic elastase II simultaneously with pancreatic elastase I in order to carry out our study.

\section{MATERIALS AND METHODS}

\section{Purification of porcine elastases I and II}

Porcine elastases I and II were purified as previously described for the isolation of human elastases I and II (Largman et al, 1976) with slight modifications. Briefly, $4 \mathrm{~g}$ acetone powder, representing $25 \mathrm{~g}$ pancreatic tissue, were suspended in $0.01 \mathrm{~mol} / \mathrm{L} \mathrm{CaCl}_{2}, 1 \mathrm{~mol} / \mathrm{L}$ Tris-base ( $\mathrm{pH} 8.0$ ), activated at $4{ }^{\circ} \mathrm{C}$ for $30 \mathrm{~min}$ with $1: 10$ (w:w) trypsin (L-1 tosylamide 2-phenylethyl chloromethyl ketone; T8642, Sigma Chemicals, St Louis, MO, USA) and centrifuged for $15 \mathrm{~min}$ at $20000 \mathrm{~g}$. The supernatant was precipitated at $\mathrm{pH} 5.1$ with $6 \%$ acetic acid and centrifuged for $10 \mathrm{~min}$ at $33000 \mathrm{~g}$. The latter supernatant was then subjected to ammonium sulfate precipitation up to $55 \%$ saturation. After centrifugation at $27000 \mathrm{~g}$ for $10 \mathrm{~min}$, the precipitate was resuspended in $0.01 \mathrm{~mol} / \mathrm{L}$ sodium phosphate $(\mathrm{pH} 6.5$ ) and dialyzed (retention threshold: $6000-8000 \mathrm{Da}$ ) for $4 \mathrm{~h}$ against water and maintained overnight against the $0.05 \mathrm{mmol} / \mathrm{L}$ sodium phosphate (pH 6.5) buffer. At the different purification steps, the retained supernatants and pellets were tested for protein content and enzymatic activities, as indicated below.

The activated material obtained was filtered through $0.45-\mu \mathrm{m}$ filters and separated on a FPLC apparatus equipped with a cation-exchange column (Mono-S, HR5/5, Pharmacia, St Quentin-enYvelines, France) equilibrated in $0.01 \mathrm{~mol} / \mathrm{L}$ sodium phosphate $(\mathrm{pH} 6.5)$ buffer. Proteins were eluted with a linear gradient of $0.01 \mathrm{~mol} / \mathrm{L}$ up to $0.2 \mathrm{~mol} / \mathrm{L}$ sodium phosphate $(\mathrm{pH} 6.5)$ buffer at a flow rate of $1 \mathrm{~mL} / \mathrm{min}$ for $50 \mathrm{~min}$. The eluate was monitored at $280 \mathrm{~nm}$ and the protein peaks measured for their protein content and potential enzymatic activities. The entire procedure was repeated several times and fractions containing either elastase I or elastase II were pooled, dialyzed overnight against water, freeze-dried, resuspended in water and stored at $-50^{\circ} \mathrm{C}$.

\section{Enzyme activity assays}

Protein content was measured as described by Lowry et al (1951). Elastase I (EC 3.4.21.36) and II (EC 3.4.21.71) activity assays were carried out at $25^{\circ} \mathrm{C}$ in $0.2 \mathrm{~mol} / \mathrm{L}$ Tris- $\mathrm{HCl}$ buffer $(\mathrm{pH} 8.0)$ with $0.01 \mathrm{~mol} / \mathrm{L}$ succinyl-L-alanyl- Lalanyl-L-alanine- $p$-nitroanilide (Suc- $\mathrm{Ala}_{3}-p \mathrm{NA}$; L1385, Bachem AG, Budendorf, Switzerland) (Bieth et al, 1974) and $0.01 \mathrm{~mol} / \mathrm{L}$ succinyl-Lalanyl-L-alanyl-L-prolyl-L-leucine-p-nitroanilide (Suc-Ala ${ }_{2}$-Pro-Leu-pNA; L1390, Bachem AG, Budendorf, Switzerland) (DelMar et al, 1980) as substrates, respectively. Elastase II substrate is known to be substantially hydrolyzed by both chymotrypsin and elastase I (especially by the latter) (DelMar et al, 1980; Largman, 1983). Therefore, chymotrypsin (EC 3.4.21.2) assays were performed at $25^{\circ} \mathrm{C}$ in $0.05 \mathrm{~mol} / \mathrm{L}$ Tris- $\mathrm{HCl}$ (pH 8.0) containing $0.02 \mathrm{~mol} / \mathrm{L} \mathrm{CaCl}_{2}$ using succinyl-L-alanyl-L-alanyl-L-prolyl-L-phenylalanine- $p$-nitroanilide (Suc-Ala - -Pro-Phe-pNA; S7388, Sigma Chemicals, St Louis, MO, USA) as substrate (DelMar et al, 1980). The resulting enzymatic units were expressed as $\mu \mathrm{mol}$ of $p$-nitroaniline released per min (IU).

\section{Sodium dodecyl sulfate (SDS) gel electrophoresis}

Cation-exchange chromatographic samples were analyzed by SDS-polyacrylamide gel electrophoresis (SDS-PAGE) using a 14\% gel under denaturing conditions and stained with Coomassie blue according to Laemmli (1970). The molecular mass marker proteins (Pharmacia Biotech, calibration kit) used were: $\alpha$-lactalbumin (14 $400 \mathrm{Da})$, soybean trypsin inhibitor (20 $100 \mathrm{Da})$, carbonic anhydrase $(30000 \mathrm{Da})$, ovalbumin (43 $000 \mathrm{Da}$ ), bovine serum albumin $(67000 \mathrm{Da})$ and phosphorylase $b(94000 \mathrm{Da})$.

\section{Hydrolysis of $\beta$-lactoglobulin}

The hydrolysis of bovine $\beta$-lactoglobulin (L3908; Sigma Chemicals, St Louis, MO, USA) was assayed as indicated by Kahn et al (1990). Hydrolytic conditions for whey protein from cow milk were those used for hypoallergenic milk preparations. $\beta$-lactoglobulin was hydrolysed by gastric, pancreatic or gastric plus pancreatic enzymes. $\beta$-lactoglobulin was incubated with 
pepsin (Bovipep, Sanofi, Beaune, France) at $42{ }^{\circ} \mathrm{C}$ for $1 \mathrm{~h}$ at $\mathrm{pH}$ 2.6. The enzyme/substrate (E/S) ratio was 1:5000 (w/w). Incubation of the $\beta$-lactoglobulin solution ( $\mathrm{pH} 8.0$ ) was performed at $37^{\circ} \mathrm{C}$ for $2 \mathrm{~h} 30$ when pancreatic enzymes were added. This yielded an E/S ratio of 1:285 for the commercial pancreatic trypsin and chymotrypsin mix (PEM 2500S, Novo-Nordisk, Bagsvaert, Denmark) and of 1:2500 for the purified elastase I and/or elastase II. Samples were quickly frozen by immersion in liquid nitrogen to stop the reaction and were then stored at $-50^{\circ} \mathrm{C}$ until chromatographic analysis. For each type of hydrolysis, a specific control was obtained under the same conditions of hydrolysis without enzyme addition.

\section{Reverse-phase chromatography}

Hydrolysates were applied to a C18 column (Vydac TP54, 100A, $4.6 \mathrm{~mm}$, L $25 \mathrm{~cm}$ ) equilibrated in $0.1 \%$ trifluoroacetic acid (TFA) solution. Elution was performed with a linear gradient of $0-80 \%$ acetonitrile in $0.1 \%$ TFA at a flow rate of $1 \mathrm{~mL} / \mathrm{min}$ for $1 \mathrm{~h}$. The percentage of $\beta$ lactoglobulin hydrolysis was determined by calculating the ratio of areas of the chromatographic peaks corresponding to non-hydrolysed $\beta$-lactoglobulin after and before hydrolysis. Proteins and peptides were monitored at $210 \mathrm{~nm}$. For each enzymatic hydrolysis, three to six assays were carried out and analysed by chromatography.

\section{Radial immunodiffusion analysis}

The antigenic property of hydrolysates was measured with the radial immunodiffusion technique of Mancini et al (1965), using rabbit antiserum raised against bovine $\beta$-lactoglobulin (Levieux, 1980). Non-hydrolysed $\beta$-lactoglobulin was used as standard. The lower limit of this method should lie at $\sim 75 \mu \mathrm{g}$ antigen. The variation between assays amounted to $2 \%$ when expressed as the standard deviation in per cent of the mean. For each sample, the residual antigenicity of $\beta$ lactoglobulin hydrolysate was calculated by removing the antigenicity due to non-hydrolysed $\beta$-lactoglobulin. The percentage of non-hydrolysed $\beta$-lactoglobulin was determined as indicated above. The residual antigenicity was expressed as a percentage of the antigenicity of the same amount of non-hydrolysed $\beta$-lac- toglobulin. Two to three determinations of residual antigenicity were carried out for each hydrolysate,

\section{RESULTS AND DISCUSSION}

\section{Purification of porcine pancreatic elastases I and II}

The different purification steps for both elastases I and II are summarized in table I. A 12.5 -fold purification of elastase I and an 8.3-fold purification of elastase II were finally achieved with a purification yield of 2.5 and $2.1 \%$, respectively. Similar degrees of purification and yields were obtained by Largman et al (1976) for the purification of human pancreatic elastases I and II. The loss of elastase II activity during the purification procedure, particularly after ionexchange chromatography, could be partially due to the separation of elastase II from elastase I and chymotrypsin. In fact, the apparent elastase II activity of pancreatic extracts during the early stages of purification represented elastase II activity potentiated to some degree by elastase I and chymotrypsin (DelMar et al, 1980; Largman, 1983).

Separation of porcine elastases I and II was easily accomplished by cation-exchange chromatography, since the two enzymes had been eluted at different salt concentrations from Mono-S. Porcine elastase I is more cationic than porcine elastase II; their $\mathrm{pHi}$ calculated from amino-acid sequences are 8.45 and 7.43 , respectively (Shotton and Hartley, 1970; Kawashima et al, 1987). The elution profile from the cation-exchange chromatography is shown in figure 1 . Five major peaks can be distinguished (table II). We can consider that elastase I constituted the main form in peak 5 and elastase II in peak 1 . In peak 5, elastase I activity is likely to be due exclusively to the elastase I enzyme, which can be responsible for the measured elastase II activity (DelMar et al, 
Table I. Purification steps for elastases I and II from porcine acetone powder.

Étapes de purification des élastases I et II à partir de poudre acétonique porcine.

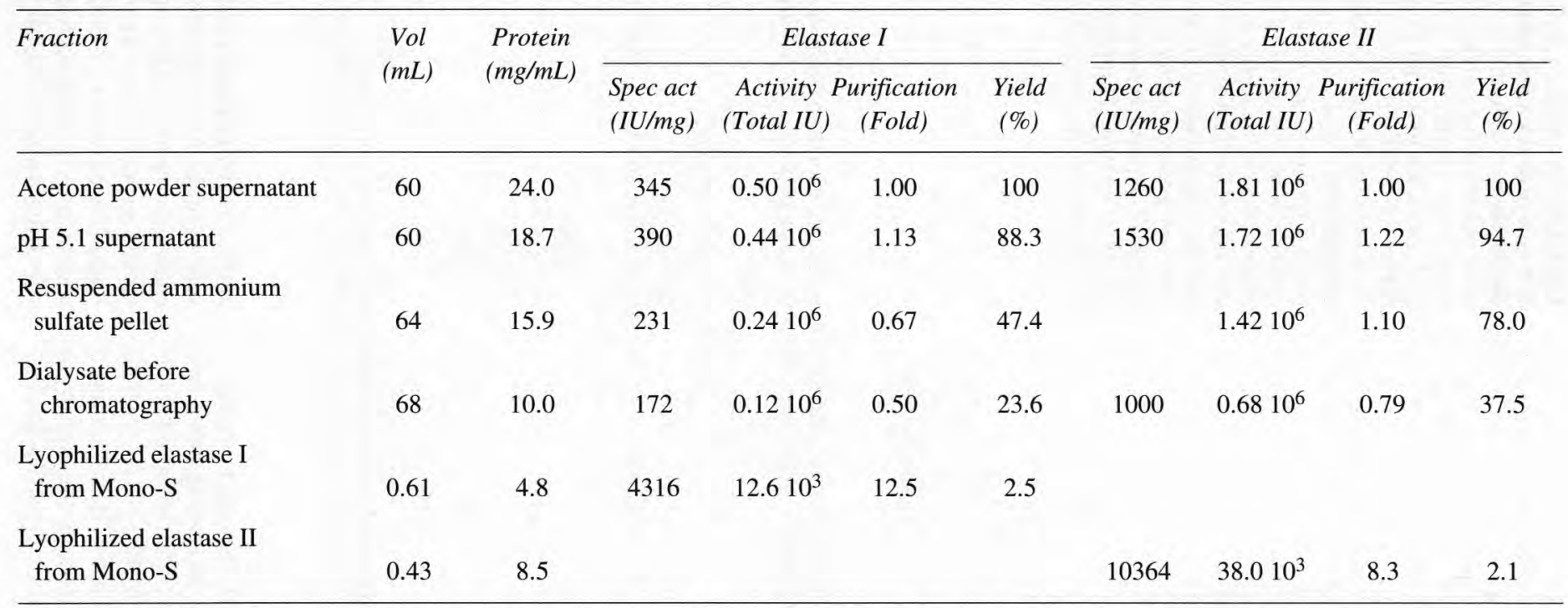

Activities of elastases I and II were determined by their abilities to degrade Suc-Ala ${ }_{3}-p$ NA and Suc- $\mathrm{Ala}_{2}$-Pro-Leu- $p$ NA substrates, as described in Materials and methods. Vol: volume; spec act: specific activity.

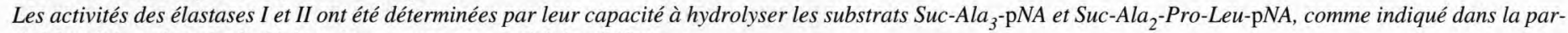
tie Materials and methods. Vol : volume; spec act : activité spécifique. 


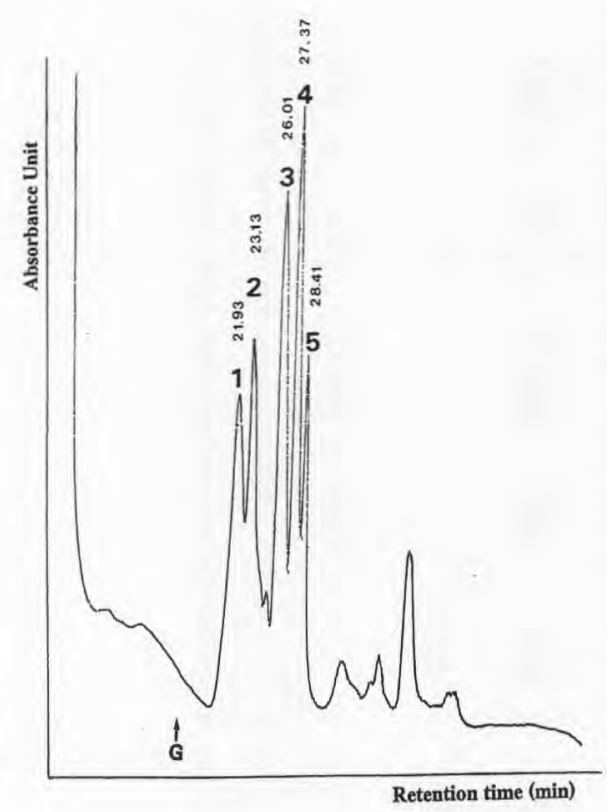

Fig 1. Elution profile of purified elastases I and II from activated porcine pancreatic acetone powder on Mono-S column. Each peak was individually collected for activity determination. Proteins were eluted with a linear gradient of $0.01 \mathrm{~mol} / \mathrm{L}$ up to $0.2 \mathrm{~mol} / \mathrm{L}$ sodium phosphate ( $\mathrm{pH}$ 6.5) buffer at a constant flow rate of $1 \mathrm{~mL} / \mathrm{min}$ for $50 \mathrm{~min}$. G indicates start of elution gradient.

Profil d'élution des élastases I et II purifiées sur colonne Mono-S à partir d'une poudre acétonique activée de pancréas de porc. Chaque pic a été collecté individuellement pour la mesure des activités enzymatiques. Les protéines sont éluées avec un gradient linéaire de 0,01 $\mathrm{mol} / \mathrm{L}$ à $0,2 \mathrm{~mol} / \mathrm{L}$ de tampon phosphate de sodium, $\mathrm{pH}$ 6,5 à flux constant ( $1 \mathrm{~mL} / \mathrm{min}$ ) pendant $50 \mathrm{~min}$. $G$ indique le début du gradient d'élution.

Table II. Protein content and specific activities of the main peaks from Mono-S chromatography. Teneur en protéines et activités spécifiques des principaux pics issus de la chromatographie sur colonne Mono-S.

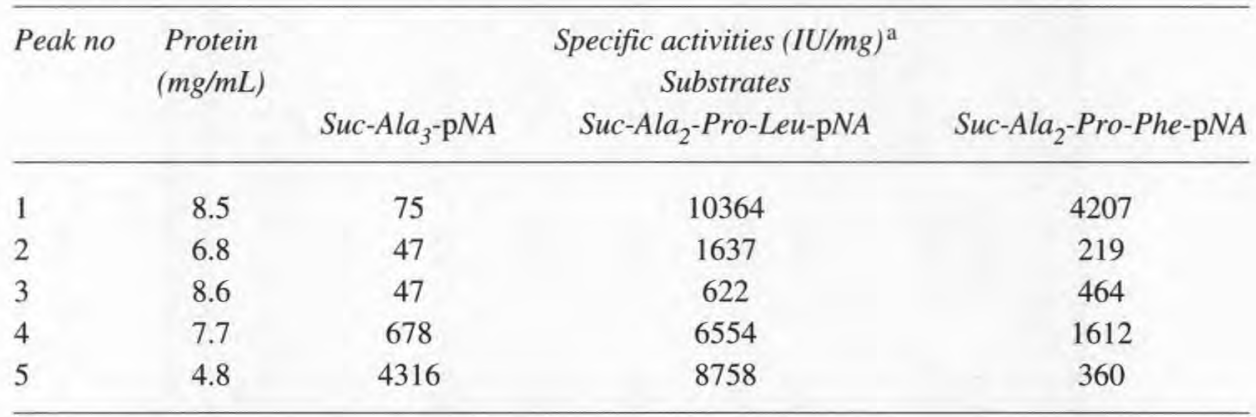

${ }^{a}$ Conditions of enzyme activity analysis have been detailed in Materials and methods.

a'Les conditions d'analyse des activités enzymatiques sont détaillées dans la partie Materials and methods.

1980; Largman, 1983). In peak 1, elastase I activity was very low, indicating that it was not eluted in this peak. The measured activity on the Suc-Ala 2 -Pro-Phe- $p$ NA substrate can only be due to elastase II, which has a hydrolytic activity towards this substrate (DelMar et al, 1980) or possibly to con- tamination by chymotrypsin. Under the present conditions of chymotrypsin activity analysis, commercial chymotrypsin demonstrated a specific activity on Suc- $\mathrm{Ala}_{2}$-ProPhe- $p$ NA equal to $27000 \mathrm{UI} / \mathrm{mg}$ protein and an activity on Suc-Ala 2 -Pro-Leu- $p$ NA substrate equal to $5600 \mathrm{UI} / \mathrm{mg}$ protein. 


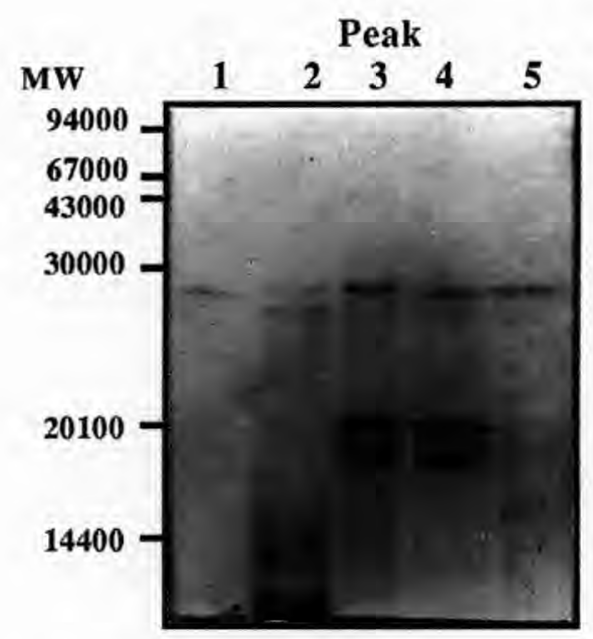

Fig 2. SDS-PAGE of $80 \mu \mathrm{g}$ of peaks (1 to 5) from Mono-S chromatography on a $14 \%$ gel stained with Coomassie blue. The molecular weight markers (MW) are indicated on the left side of the gel. The molecular weight of the elastases I and II was estimated at approximately 27500.

Électrophorèse sur gel de polyacrylamidebisacrylamide à $14 \%$ en présence de SDS, de $80 \mu \mathrm{g}$ de protéines des pics 1 à 5 de la chromatographie sur colonne Mono-S. Le gel a été coloré au bleu de Coomassie. Les marqueurs de poids moléculaire $(M W)$ sont indiqués sur la partie gauche du gel. Le poids moléculaire des élastases I et II a été estimé à environ 27500.

Therefore, contamination by chymotrypsin could only be minor. Moreover, the three substrates were not or insignificantly hydrolysed by trypsin. The other peaks did not display such a high enzymatic activity towards elastase I and II substrates.

The purified elastases were then tested for their homogeneity by SDS-polyacrylamide gel electrophoresis (SDS-PAGE) using a $14 \%$ gel under denaturing conditions (fig 2). The migration pattern of peaks 1 and 5 presented a single band. No contamination with chymotrypsin, trypsin or other proteins was observed for these peaks. The molecular weight of these bands was estimated to be $\sim 27500$, which was in agreement with the theoretical molecular weight of elastases I and II (Shotton and Hartley, 1970; Kawashima et al, 1987). When wells were overloaded, two slight bands migrating as chymotrypsin could be detected (data not shown) corroborating activity analysis (table II).

\section{Enzymatic hydrolysis of $\beta$-lactoglobulin}

The chromatographic profiles of $\beta$-lactoglobulin hydrolysis by different enzymes or mix of enzymes are shown in figures 3 and 4 . The percentage of hydrolysis obtained for the various hydrolysates and the residual antigenicity of these hydrolytic products are presented in table III. A striking difference was observed in the pattern of peptidic fragments formed by the action of each elastase. The elution profile of the hydrolysate produced by elastase I action showed one major peak of relatively high hydrophobicity. In contrast, elastase II hydrolysis indicated a large number of lower hydrophobicity peptides in addition to a major peak of high hydrophobicity. The percentage of hydrolysis of $\beta$-lactoglobulin was 2 -fold higher with elastase II than with elastase I. In contrast, Schmidt and Poll (1991) indicated that only small peptides had been released from $\beta$-lactoglobulin when hydrolysis was performed with elastase I. Hydrolysis of $\beta$-lactoglobulin with pepsin plus pancreatic trypsin and chymotrypsin mix greatly increased the percentage of hydrolysis (table III) and the number of peptide peaks (fig 4). These enzymatic hydrolysis resulted in the production of a greater variety of more hydrophylic peptides. The action of pepsin plus pancreatic trypsin and chymotrypsin simultaneously with that of elastase I or II did not change the percentage of hydrolysis. However, the nature and the number of peptides were modified.

Hydrolysis with elastase I or II alone was effective in reducing the residual antigenicity 


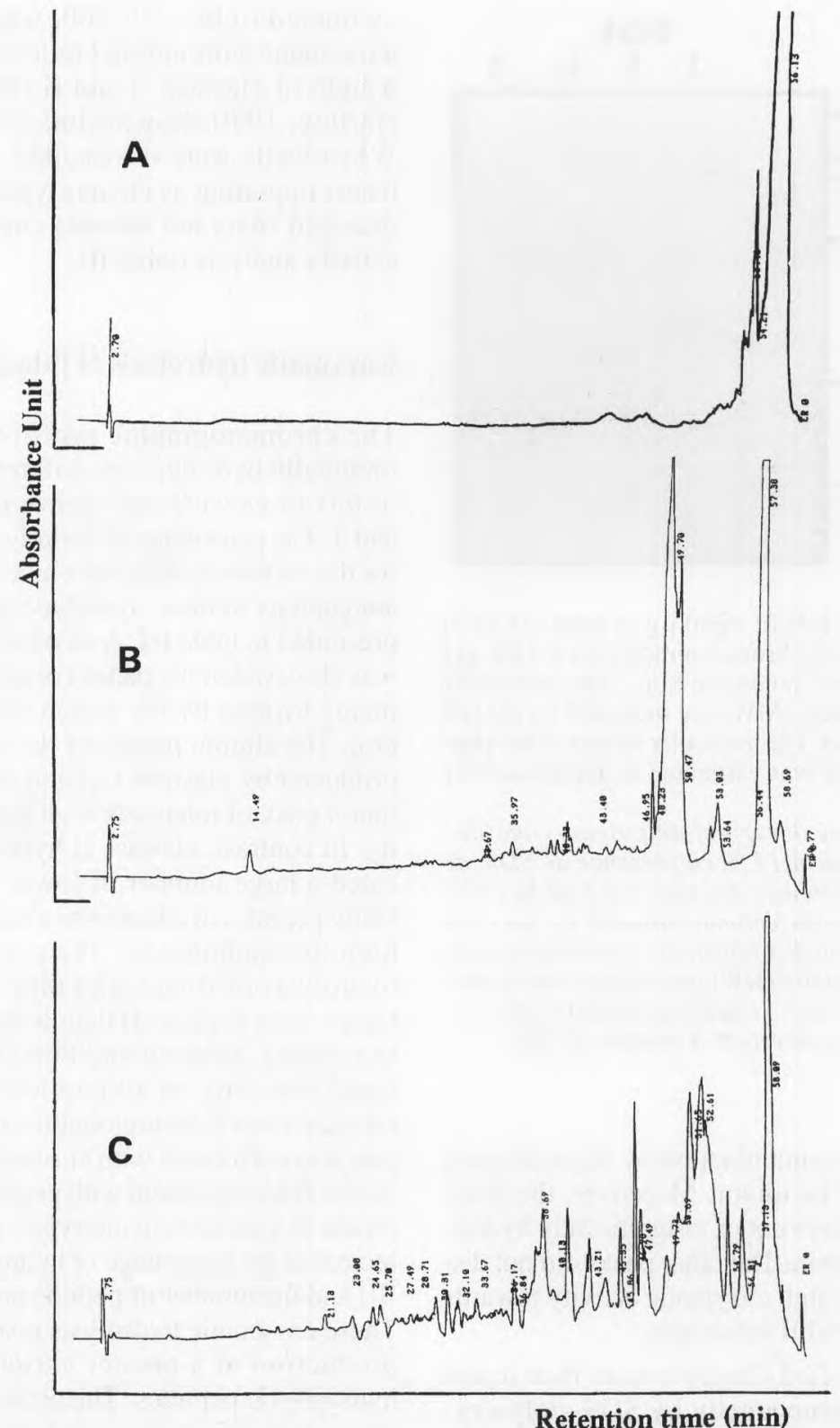

Fig 3. Reverse-phase chromatography elution profile of $\beta$-lactoglobulin in control (A) or after $2 \mathrm{~h} 30$ proteolysis by purified elastase I (B) or elastase II (C) (E/S ratio was $1: 2500)$. Flow rate was $1 \mathrm{~mL} / \mathrm{min}$ in $0.1 \%$ TFA solution. A linear gradient of $0-80 \%$ acetonitrile/ $0.1 \%$ TFA solution was applied over $1 \mathrm{~h}$. Chromatographie en phase inverse de la $\beta$-lactoglobuline contôle (A) ou après $2 \mathrm{~h} 30$ de protéolyse par l'élastase I (B) ou l'élastase II (C) purifiées (le rapport E/S est de 1:2500). La vitesse d'élution est de $1 \mathrm{~mL} / \mathrm{min}$ avec une solution de TFA à $0,1 \%$. Un gradient linéaire de $0-80 \%$ d'acétonitrile dans une solution de TFA à 0,1 \% est réalisé pendant $1 \mathrm{~h}$. 


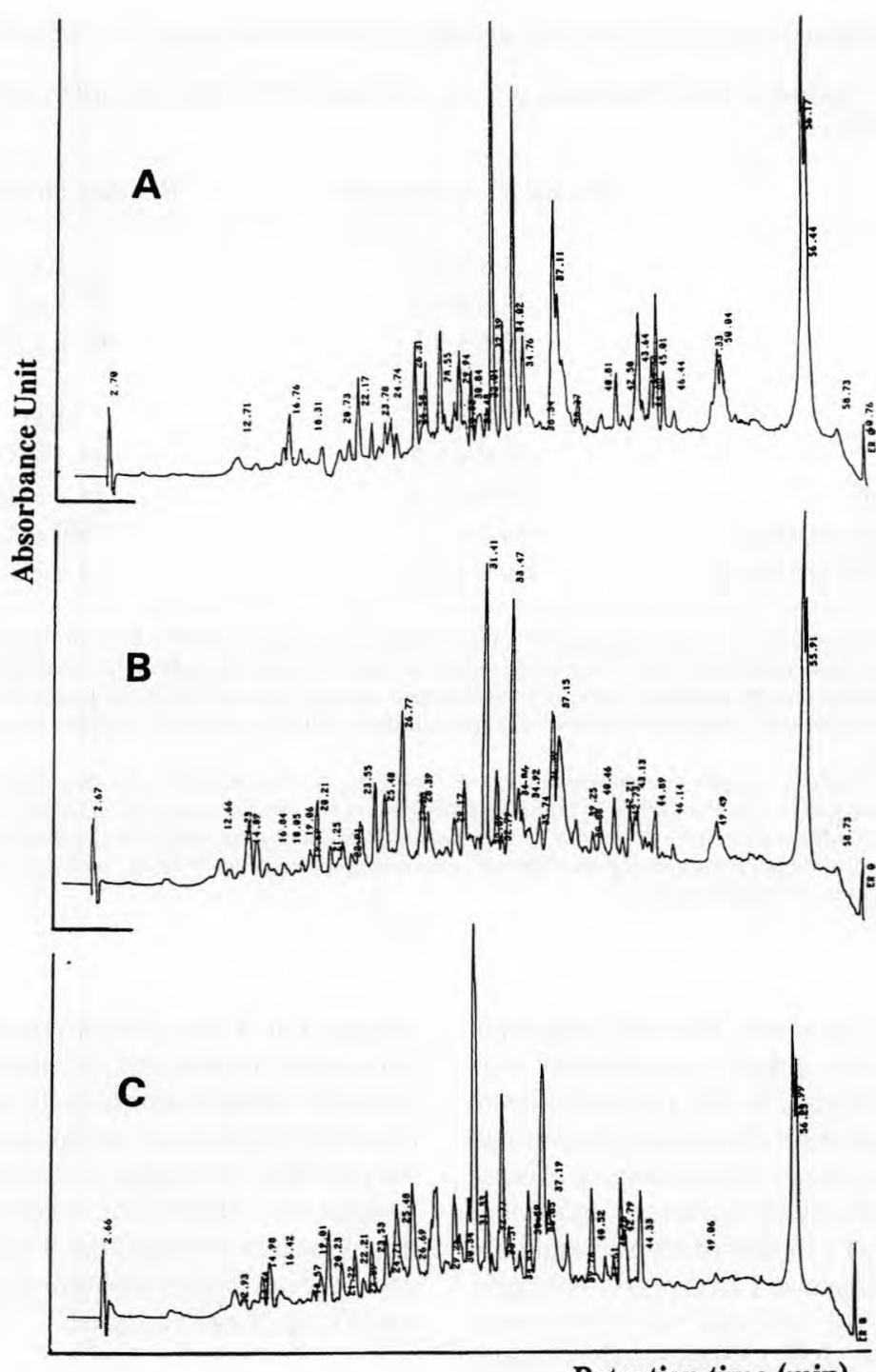

Retention time (min)

Fig 4. Reverse-phase chromatography elution profile of $\beta$-lactoglobulin after 1 h hydrolysis by pepsin (E/S ratio was 1:5000) followed by $2 \mathrm{~h} 30$ proteolysis with pancreatic trypsin and chymotrypsin mix (E/S ratio was $1: 285)$ alone $(\mathrm{A})$ or in the presence of purified elastase $\mathrm{I}(\mathrm{B})$ or elastase II (C) (E/S ratio was 1:2500). Flow rate was $1 \mathrm{~mL} / \mathrm{min}$ in $0.1 \%$ TFA solution. A linear gradient of $0-80 \%$ acetonitrile $/ 0.1 \%$ TFA solution was applied over $1 \mathrm{~h}$.

Chromatographie en phase inverse de la $\beta$-lactoglobuline après 1 h d'hydrolyse par la pepsine (le rapport E/S est de 1:5000) et $2 \mathrm{~h} 30$ de protéolyse par un mélange de trypsine et de chymotrypsine pancréatiques (le rapport E/S est de 1:285) seul (A) ou en présence d'élastase I (B) ou d'élastase II (C) purifiées (le rapport E/S est de 1:2500). La vitesse d'élution est de $1 \mathrm{~mL} / \mathrm{min}$ avec une solution de TFA à $0,1 \%$. Un gradient linéaire de 0-80\% d'acétonitrile dans une solution de TFA à $0,1 \%$ est réalisé pendant $1 \mathrm{~h}$. 
Table III. Percentage of hydrolysis of $\beta$-lactoglobulin and residual antigenicity in various hydrolysates (means $\pm \mathrm{SE}$ ).

Pourcentage d'hydrolyse de la $\beta$-lactoglobuline et antigénicité résiduelle des différents hydrolysats (moyenne $\pm S E$ ).

\begin{tabular}{|c|c|c|}
\hline Enzyme & Percentage of hydrolysis & Residual antigenicity ${ }^{\mathrm{a}}$ \\
\hline Control $1^{\mathrm{b}}$ & $5.6 \pm 0.7$ & 100 \\
\hline Elastase I & $33.6 \pm 6.3$ & $60.5 \pm 2.1$ \\
\hline Elastase II & $62.6 \pm 8.5$ & $42.2 \pm 6.0$ \\
\hline Control $2^{\mathrm{c}}$ & $5.7 \pm 0.3$ & 100 \\
\hline Pepsin & $26.8 \pm 1.2$ & $44.4 \pm 3.0$ \\
\hline Pepsin + PEM $^{d}$ & $86.0 \pm 2.4$ & $14.3 \pm 2.6$ \\
\hline Pepsin + PEM + elastase I & $89.2 \pm 2.5$ & $9.9 \pm 3.7$ \\
\hline Pepsin + PEM + elastase II & $89.3 \pm 1.9$ & $7.1 \pm 1.1$ \\
\hline
\end{tabular}

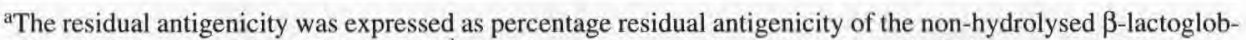

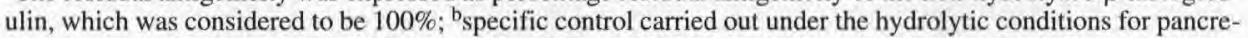
atic enzymes without enzyme addition; ${ }^{c}$ specific control carried out under the conditions for gastric hydrolysis alone or followed by pancreatic hydrolysis without enzyme addition; ${ }^{\mathrm{d}} \mathrm{PEM}$ : pancreatic enzyme (trypsin and chymotrypsin) mix.

${ }^{a} L$ 'antigénicité résiduelle est exprimée en pourcentage de l'antigénicité résiduelle de la $\beta$-lactoglobuline non hydrolysée qui est considérée égale à $100 \%$; ${ }^{b}$ contrôle réalisé dans les conditions d'hydrolyse des enzymes pancréatiques, sans addition d'enzymes ; contrôle réalisé dans les conditions d'hydrolyse de l'enzyme gastrique seule ou suivie de l'hydrolyse par les enzymes pancréatiques, sans addition d'enzymes; 'PEM : mélange d'enzymes pancréatiques (trypsine et chymotrypsine).

of hydrolytic products. The most important reduction in residual antigenicity was obtained by treatment with pepsin followed by hydrolysis with pancreatic trypsin and chymotrypsin mix in the presence of elastase II. The specificity of elastases I and II was complementary to that of trypsin and chymotrypsin. Elastase I hydrolysis is largely limited to Ala-Ala and Ala-Gly bonds (Gertler et al, 1977). Elastase II preferentially cleaves the bonds formed between leucine, phenylalanine or tyrosine with glycine or alanine (Gertler et al, 1977; DelMar et al, 1980). The presence of elastase I in pancreatic trypsin and chymotrypsin mix tended to reduce the residual antigenicity. The decrease was enhanced in the presence of elastase II. The percentage of hydrolysis of $\beta$-lactoglobulin was not the only parameter influencing the antigenicity. The same percentage of hydrolysis was observed when elastase I or II was added to pepsin plus the pancreatic trypsin and chymotrypsin mix while the residual antigenicity tended to be lower in the presence of elastase II than in the presence of elastase I. As suggested by Asselin et al (1989), the relative sensitivities of the peptide bonds involved in the antigenic sites of $\beta$-lactoglobulin depend on the specificity of each enzyme.

\section{CONCLUSION}

In conclusion, this study clearly demonstrates the importance and specificity of elastase I and particularly of elastase II in enhancing $\beta$-lactoglobulin hydrolysis and in reducing the residual antigenicity of the hydrolytic products. However, as regards industrial application, the intact $\beta$-lactoglobulin remaining in the hydrolysates 
should always be removed. This could be achieved by modifying the conditions of enzyme hydrolysis (E/S ratio, hydrolysis time, etc) and by removing $\beta$-lactoglobulin via ultrafiltration (Asselin et al, 1988). Nevertheless, this improvement in the hydrolysis of $\beta$-lactoglobulin requires further investigation to determine its efficiency under production conditions for hypoallergenic infant food formula. It would appear that the hydrolysis of $\beta$-lactoglobulin and of $\alpha$-lactalbumin occurs at a considerably lower rate when these are present in crude rather than in purified form (Jakobsson et al, 1982 and 1983).

\section{ACKNOWLEDGMENTS}

Thanks are due to J Quillet for the bibliographical information, T Efstathiu, P Lorthioir and M Piot for technical advice, J Léonil for reviewing the manuscript and D Fontaine for the English revision of the manuscript. Financial grants to $\mathrm{M}$ Gestin from the Conseil régional de Bretagne and the Centre National Interprofessionnel d'Economie Laitière are gratefully acknowledged.

\section{REFERENCES}

Asselin J, Amiot J, Gauthier SF, Mourad W, Hebert J (1988) Immunogenicity and allergenicity of whey protein hydrolysates. $J$ Food Sci 53, 1208-1211

Asselin J, Hebert J, Amiot J (1989) Effects of in vitro proteolysis on the allergenicity of major whey proteins. J Food Sci 54, 1037-1039

Bieth J, Spiess B, Wermuth CG (1974) The synthesis and analytical use of a highly sensitive and convenient substrate of elastase. Biochem Med 11, 350357

DelMar EG, Largman C, Brodrick JW, Fassett M, Geokas MC (1980) Substrate specificity of human pancreatic elastase 2. Biochemistry 19, 468-472

Gertler A, Weiss Y, Burstein Y (1977) Purification and characterization of porcine elastase II and investigation of its elastolytic specificity. Biochemistry $16,2709-2716$

Heppell LMJ, Cant AJ, Kilshaw PJ (1984) Reduction in the antigenicity of whey proteins by heat treat- ment: a possible strategy for producing a hypoallergenic infant milk formula. Br J Nutr 51, 29-36

Jakobsson I, Lindberg T, Benediktsson B (1982) In vitro digestion of cow's milk proteins by duodenal juice from infants with various gastrointestinal disorders. J Pediatr Gastroenterol Nutr 1, 183-191

Jakobsson I, Borulf S, Lindberg T, Benediktsson B (1983) Partial hydrolysis of cow's milk proteins by human trypsins and elastases in vitro. $J$ Pediatr Gastroenterol Nutr 2, 613-616

Jost R, Monti JC, Pahud JJ (1987) Whey protein allergenicity and its reduction by technological means. Food Technol 41, 118-121

Kahn JM, Mendy F, Roger L (1990) Improvements in or relating to organic compounds. Patent EP 0421309

Kawashima I, Tani T, Shimoda K, Takigichi Y (1987) Characterization of pancreatic elastase II-cDNAs: two elastase II mRNAs are expressed in human pancreas. DNA 6, 163-172

Laemmli UK (1970) Cleavage of structural proteins during the assembly of the head of bacteriophage T4. Nature $227,680-685$

Largman C (1983) Isolation and characterization of rat pancreatic elastase. J Bial Chem 258, 2327 2333

Largman C, Brodrick JW, Geokas MC (1976) Purification and characterization of two human pancreatic elastases. Biochemistry 15, 2491-2500

Lowry OH, Rosebrough NJ, Farr AL, Randall RJ (1951) Protein measurement with the folin phenol reagent. J Biol Chem 193, 165-175

Levieux D (1980) Heat denaturation of whey proteins. Comparative studies with the physical and immunological methods. Ann Res Vet 11, 89-97

Mancini G, Carbonara AO, Heremans JF (1965) Immunochemical quantitation of antigens by single radial immunodiffusion. Immunochemistry 2, 235254

Mason S (1962) Some aspects of gastric function in the newborn. Arch Dis Child 37, 387-391

Pahud JJ, Monti JC, Jost R (1985) Allergenicity of whey protein: its modification by tryptic in vitro hydrolysis of the protein. J Pediatr Gastroenterol Nutr 4, 408-413

Rigo J, Salle BL, Putet G, Senterre J (1994) Nutritional evaluation of various protein hydrolysate formulae in term infants during the first month of life. Acta Paediatr 83, 100-104

Schmidt DG, Poll JK (1991) Enzymatic hydrolysis of whey proteins - hydrolysis of $\alpha$-lactalbumin and $\beta$-lactoglobulin in buffer solutions by proteolytic enzymes. Neth Milk Dairy J 45, 225-240

Shotton DM, Hartley BS (1970) Amino-acid sequence of porcine pancreatic elastase and its homologies with other serine proteinases. Nature 225, 802-806 